\title{
Efficacy and safety of exogenous melatonin for secondary sleep disorders and sleep disorders accompanying sleep restriction: meta-analysis
}

Nina Buscemi, Ben Vandermeer, Nicola Hooton, Rena Pandya, Lisa Tjosvold, Lisa Hartling, Sunita Vohra, Terry P

Klassen, Glen Baker

\begin{abstract}
Objective To conduct a systematic review of the efficacy and safety of exogenous melatonin in managing secondary sleep disorders and sleep disorders accompanying sleep restriction, such as jet lag and shiftwork disorder.

Data sources 13 electronic databases and reference lists of relevant reviews and included studies; Associated Professional Sleep Society abstracts (1999 to 2003).

Study selection The efficacy review included randomised controlled trials; the safety review included randomised and non-randomised controlled trials.

Quality assessment Randomised controlled trials were assessed by using the Jadad Scale and criteria by Schulz et al, and non-randomised controlled trials by the Downs and Black checklist.

Data extraction and synthesis One reviewer extracted data and another reviewer verified the data extracted. The inverse variance method was used to weight studies and the random effects model was used to analyse data.

Main results Six randomised controlled trials with 97 participants showed no evidence that melatonin had an effect on sleep onset latency in people with secondary sleep disorders (weighted mean difference - 13.2 (95\% confidence interval -27.3 to 0.9 ) $\mathrm{min}$ ). Nine randomised controlled trials with 427 participants showed no evidence that melatonin had an effect on sleep onset latency in people who had sleep disorders accompanying sleep restriction $(-1.0(-2.3$ to 0.3$) \mathrm{min}) .17$ randomised controlled trials with 651 participants showed no evidence of adverse effects of melatonin with short term use (three months or less).

Conclusions There is no evidence that melatonin is effective in treating secondary sleep disorders or sleep disorders accompanying sleep restriction, such as jet lag and shiftwork disorder. There is evidence that melatonin is safe with short term use.
\end{abstract}

\section{Introduction}

Sleep disorders affect approximately $20 \%$ of the American population. ${ }^{1}$ A sleep disorder exists whenever a lower quality of sleep leads to impaired functioning or excessive sleepiness. ${ }^{2}$ Sleep disorders place a burden on society due to their negative impact on quality of life, safety, productivity, and healthcare utilisation.
One category of sleep disorders is secondary sleep disorders, sleep problems that are associated with medical, neurological, or substance misuse disorders. Another category of sleep disorders arises from sleep restriction: inadequate sleep results from imposed or self imposed lifestyle and work schedules, such as air travel and shift work. ${ }^{1}$

Complementary and alternative medicine has been used increasingly to manage sleep disorders. One of the most popular treatments of this type is melatonin, a hormone that is secreted by the pineal gland and is linked to the circadian rhythm. ${ }^{3}$

We conducted a systematic review of the efficacy and safety of exogenous melatonin in managing secondary sleep disorders and sleep disorders accompanying sleep restriction, such as jet lag and shiftwork disorder. Our findings can help to guide clinicians and patients in treatment decisions regarding the use of exogenous melatonin in the management of these conditions.

\section{Methods}

\section{Search strategy}

A health sciences librarian conducted a comprehensive search to identify relevant English-language studies. We searched 13 electronic databases (table 1; see bmj.com for search terms). The reference lists of relevant reviews, as well as a random sample of included studies, were reviewed to identify other potentially relevant studies. We hand searched abstracts of meetings of the Associated Professional Sleep Society from 1999 to 2003. Finally, we searched Medline and Embase again in early 2004 to identify recently published studies.

\section{Study selection}

The full text of all articles deemed potentially relevant was retrieved and reviewed independently by two reviewers. To assess the efficacy of exogenous melatonin, we included randomised controlled trials that involved human participants who had a secondary sleep disorder or a sleep disorder accompanying sleep restriction; compared melatonin to placebo; and reported on one or more of: sleep onset latency (amount of time between lying down to sleep and onset of sleep), sleep efficiency (amount of time spent asleep as a percentage of total time spent in bed), sleep quality (perceived quality of sleep), wakefulness after sleep onset (amount of time spent awake in bed after first attainment

Search terms used are on bmj.com 
Table 1 Biomedical databases searched for articles on exogenous melatonin in managing secondary sleep disorders and sleep disorders accompanying sleep restriction

\begin{tabular}{|c|c|c|}
\hline Database & Platform & Dates covered by search \\
\hline Medline & Ovid & 1966 to 30 June 2003 \\
\hline PreMedline & Ovid & $\begin{array}{l}1970 \text { to } 30 \text { June and } 4 \\
\text { July } 2003\end{array}$ \\
\hline Embase & Ovid & 1988 to 30 June 2003 \\
\hline PubMed & NA & 1950 to 9 July 2003 \\
\hline CAB Health & SilverPlatter version 4.3 & 1973 to 8 July 2003 \\
\hline CINAHL & Ovid & 1982 to 30 June 2003 \\
\hline $\begin{array}{l}\text { Cochrane Central Register } \\
\text { of Controlled Trials }\end{array}$ & Ovid & $\begin{array}{l}\text { 3rd quarter 2003; } 2 \text { July } \\
2003\end{array}$ \\
\hline Science Citation Index & ISI Web of Knowledge & 1945 to 4 July 2003 \\
\hline Biological Abstracts & SilverPlatter version 4.3 & 1969 to 4 July 2003 \\
\hline $\begin{array}{l}\text { International } \\
\text { Pharmaceutical } \\
\text { Abstracts }\end{array}$ & Ovid & 1970 to 12 August 2003 \\
\hline NLM Gateway & http://gateway.nlm.nih.gov/gw/Cmd & 1950 to 13 August 2003 \\
\hline $\begin{array}{l}\text { OCLC Papers First and } \\
\text { Proceedings First }\end{array}$ & OCLC FirstSearch & 1993 to 11 July 2003 \\
\hline Toxline & CSA Internet Database Service & 1965 to 4 July 2003 \\
\hline
\end{tabular}

of sleep), total sleep time (total time spent asleep while in bed), or percentage of time in rapid eye movement (REM) sleep.

To assess the safety of exogenous melatonin, we included randomised and non-randomised trials meeting the first two criteria above and reporting on adverse events. A study population was considered to have a secondary sleep disorder if the participants, as a group, were defined by a specific chronic medical or psychiatric disorder and this disorder was likely to be the cause of the sleep disorder. A study population was considered to have been exposed to sleep restriction if participants had been exposed to transmeridian air travel, shiftwork, or other forms of sleep schedule alteration. Disagreements regarding inclusion of studies were resolved through discussion.

\section{Quality assessment}

Two reviewers assessed study quality independently. For the efficacy review, randomised controlled trials were assessed for methodological quality with the validated Jadad scale. ${ }^{4}$ In addition, concealment of treatment allocation was assessed using the criteria of Schulz et al. ${ }^{5}$ Allocation concealment was considered to be adequate if group allocation was accomplished by using such methods as central randomisation, numbered or coded containers, drugs prepared by a pharmacy, or serially numbered, opaque, sealed envelopes. For the safety review, which relied on evidence from randomised and non-randomised trials, the Downs and Black checklist was used. ${ }^{6}$ Disagreements regarding quality assessment were resolved through discussion.

\section{Data extraction}

Data were extracted by using a standardised data extraction form that captured details of study design, population, intervention, and outcomes. A trained reviewer extracted data and a second reviewer verified the extracted data. Disagreements were resolved through discussion.

\section{Data analysis}

We listed our outcomes in order of importance, with sleep onset latency as most important (primary outcome), followed by sleep efficiency, sleep quality, wakefulness after sleep onset, total sleep time, and percentage of time in REM sleep. Continuous outcomes were combined, using a weighted mean difference, with the exception of sleep quality, for which studies were combined by using a standardised mean difference. Dichotomous outcomes were combined by using a risk difference. The inverse variance method was used to weight the studies. ${ }^{7}$ All meta-analyses used a random effects model. A point estimate with corresponding 95\% confidence interval was computed for each outcome, using the generic inverse variance function in RevMan 4.2.5 (Update Software, 2004).

In most cases, we were able to calculate the efficacy estimate for each study exactly, but occasionally estimates had to be made by extracting from graphs or using medians. Standard errors of the differences were calculated from available data (individual patient data or exact $\mathrm{P}$ values) whenever possible. For studies with a crossover design, we used the methods of Elbourne et al to compute standard errors of differences, ${ }^{8}$ and a correlation of 0.5 was imputed when it could not be calculated from available data.

All pooled estimates were assessed for heterogeneity, using the $\mathrm{I}^{2}$ statistic. ${ }^{9}$ For our primary outcome, we planned to explore heterogeneity in subgroup and sensitivity analyses. We also conducted a post hoc sensitivity analysis. Deeks' $\chi^{2}$ statistic $^{10}$ was used to test for significant heterogeneity reduction in partitioned subgroups (age, comorbidity, type of sleep disorder, dosage, treatment duration, outcome measurement method, study design, study quality, and allocation concealment).

We tested for publication bias visually using the funnel plot and quantitatively using the rank correlation test, ${ }^{11}$ the graphical test, ${ }^{12}$ and the trim and fill method. ${ }^{13}$ Publication bias graphs and calculations were produced with STATA 7.0 (Stata Corporation, 2001).

\section{Results}

Figure 1 shows the flow of studies through the selection process.

\section{Secondary sleep disorders}

Efficacy

Table 2 describes the nine trials (279 participants) included in the efficacy analysis for secondary sleep disorders. ${ }^{14-25}$ The median quality score, based on the Jadad scale, was 4 out of 5 (interquartile range 2-4). Concealment of allocation was unclear in all studies except one, ${ }^{23}$ which had adequate allocation concealment. Only five studies described a funding source; for all of these studies, funding was received from public sponsors. ${ }^{18-23}$

\section{Sleep onset latency}

Table 3 outlines the means and standard deviations for sleep onset latency for placebo and melatonin groups for the six trials providing data on this outcome..$^{15} 18{ }^{191-23}$ The studies produced a combined estimate that favoured melatonin but was not significant (weighted mean difference - 13.2 (95\% confidence interval -27.3 to 0.9 ) $\mathrm{min}$ ) (fig 2). Heterogeneity among the studies was substantial $\left(\mathrm{I}^{2}=79.2 \%\right)$ due primarily to one study ${ }^{23}$ that had a very small standard deviation and an estimate that favoured placebo, whereas the other studies had point estimates that favoured melatonin.

The results for planned subgroup and sensitivity analyses are shown in table 4 . In the only two categories for which the confidence intervals across subgroups did not overlap, a study by Shamir et al seemed to be highly influential..$^{23}$ Subgroups that omitted this study (actigraphy and questionnaire methods of measuring sleep outcomes and unclear allocation concealment) showed a significant result in favour of melatonin with minimal heterogeneity, while the point estimate for this study showed a significant effect in favour of placebo.

We conducted a post hoc sensitivity analysis excluding the study by Shamir et al from the primary analysis. When the study was included in the analysis, the point estimate was -13.2 
Research

Table 2 Characteristics of trials of melatonin in people with secondary sleep disorders

\begin{tabular}{|c|c|c|c|c|c|c|c|c|}
\hline \multirow[b]{2}{*}{ Study and year } & \multirow[b]{2}{*}{$\begin{array}{l}\text { No enrolled } \\
\text { (analysed) }\end{array}$} & \multirow[b]{2}{*}{$\begin{array}{l}\text { Mean (SD or range) } \\
\text { age (years) }\end{array}$} & \multirow[b]{2}{*}{$\%$ male } & \multirow[b]{2}{*}{ Disorder } & \multicolumn{3}{|c|}{ Intervention } & \multirow[b]{2}{*}{ Design } \\
\hline & & & & & Formulation & $\begin{array}{l}\text { Dosage and timing } \\
\text { (route) }\end{array}$ & $\begin{array}{l}\text { Frequency and } \\
\text { duration }\end{array}$ & \\
\hline $\begin{array}{l}\text { Camfield et al, } \\
1996^{14 \star}\end{array}$ & 6 & 8.8 (3 to 13) & 67 & $\begin{array}{l}\text { Developmental } \\
\text { disability }\end{array}$ & NS & $\begin{array}{l}0.5 \text { or } 1.0 \mathrm{mg} \text { at } 1800 \\
\text { (oral) }\end{array}$ & $\begin{array}{l}\text { For each } 2 \text { week } \\
\text { interval of } 10 \text { week } \\
\text { trial, children received } \\
\text { melatonin or placebo } \\
\text { nightly during first } \\
\text { week with alternative } \\
\text { agent given on second } \\
\text { week }\end{array}$ & N-of-1 RCT \\
\hline $\begin{array}{l}\text { Dodge and } \\
\text { Wilson, } \\
2001^{15}\end{array}$ & $36(17)$ & 7.4 (1 to 15$)$ & NS & $\begin{array}{l}\text { Developmental } \\
\text { disability }\end{array}$ & NS & $5 \mathrm{mg}$ at 2000 (oral) & $\begin{array}{l}5 \mathrm{mg} / \text { day for weeks 2- } \\
3 \text { and } 5-6 \text { of } 6 \text { week } \\
\text { study }\end{array}$ & RCT; crossover \\
\hline $\begin{array}{l}\text { Jan et al, } \\
1994^{16} \dagger\end{array}$ & 15 & NS $(0.5-14)$ & 87 & $\begin{array}{l}\text { Neurological } \\
\text { impairment }\end{array}$ & NS & $\begin{array}{l}2-5 \mathrm{mg} \text { at bedtime } \\
\text { (NS) }\end{array}$ & $\begin{array}{l}2-5 \mathrm{mg} / \text { day for up to } \\
12 \text { months }\end{array}$ & N-of-1 RCT \\
\hline $\begin{array}{r}\text { Jean-Louis et } \\
\text { al, } 1998^{17} \dagger \\
\end{array}$ & 10 & $68.8(15.8)$ & 40 & $\begin{array}{l}\text { Mild cognitive } \\
\text { impairment }\end{array}$ & NS & $\begin{array}{l}6 \mathrm{mg} 2 \mathrm{~h} \text { before } \\
\text { bedtime (NS) }\end{array}$ & $6 \mathrm{mg} /$ day for 10 days & $\begin{array}{l}\text { Non-RCT; } \\
\text { crossover }\end{array}$ \\
\hline $\begin{array}{l}\text { McArthur and } \\
\text { Budden, } \\
1998^{18}\end{array}$ & 9 & $10.1(1.5)$ & 0 & Rett syndrome & Immediate release & $\begin{array}{l}2.5-7.5 \mathrm{mg} \text { (depending } \\
\text { on body weight) given } \\
1 \mathrm{~h} \text { before bedtime } \\
\text { (oral or gastrostomy } \\
\text { tube) }\end{array}$ & $\begin{array}{l}1 \text { capsule/day for } 4 \\
\text { weeks }\end{array}$ & RCT; crossover \\
\hline $\begin{array}{l}\text { O'Callaghan et } \\
\text { al, } 1999^{19}\end{array}$ & 7 & Median=11 (2-28) & 43 & Tuberous sclerosis & NS & $\begin{array}{l}5 \mathrm{mg} 20 \mathrm{~min} \text { before } \\
\text { bedtime (oral) }\end{array}$ & $\begin{array}{l}1 \text { capsule/day for } 2 \\
\text { weeks }\end{array}$ & RCT; crossover \\
\hline $\begin{array}{l}\text { Serfaty et al, } \\
2002^{20}\end{array}$ & $44(25)$ & $84.2(7.6)$ & 64 & Dementia & Slow release & $\begin{array}{l}6 \mathrm{mg} \text { tablet at usual } \\
\text { bedtime (oral) }\end{array}$ & $\begin{array}{l}1 \text { tablet/day for } 2 \\
\text { weeks }\end{array}$ & RCT; crossover \\
\hline $\begin{array}{l}\text { Serfaty et al, } \\
2003^{21 *}\end{array}$ & $33(31)$ & $39.9(11.8)$ & 45 & Major depression & Slow release & $\begin{array}{l}6 \mathrm{mg} \text { tablet at bedtime } \\
\text { (oral) }\end{array}$ & $\begin{array}{l}1 \text { tablet/day for } 4 \\
\text { weeks }\end{array}$ & RCT; parallel \\
\hline $\begin{array}{l}\text { Shamir et al, } \\
2000^{22 \star}\end{array}$ & $27(19)$ & $42(5)$ & 63 & Schizophrenia & Controlled release & $\begin{array}{l}2 \mathrm{mg} 2 \mathrm{~h} \text { before } \\
\text { bedtime (NS) }\end{array}$ & $2 \mathrm{mg} /$ day for 3 weeks & RCT; crossover \\
\hline $\begin{array}{l}\text { Shamir et al, } \\
2000^{23 \star}\end{array}$ & 14 & $42.3(13.1)$ & 79 & Schizophrenia & Controlled release & $\begin{array}{l}2 \mathrm{mg} 2 \mathrm{~h} \text { before } \\
\text { bedtime (NS) }\end{array}$ & $2 \mathrm{mg} /$ day for 3 weeks & RCT; crossover \\
\hline $\begin{array}{l}\text { Singer et al, } \\
2003^{24 *}\end{array}$ & $157(151)$ & 77.4 (8.9) & 44 & Alzheimer's disease & $\begin{array}{l}\text { Slow release and } \\
\text { immediate release }\end{array}$ & $\begin{array}{l}2.5 \mathrm{mg} \text { (SR) or } 10 \mathrm{mg} \\
\text { (IR) } 1 \mathrm{~h} \text { before bedtime } \\
\text { (oral) }\end{array}$ & $\begin{array}{l}1 \text { capsule/day for } 8 \\
\text { weeks }\end{array}$ & RCT; parallel \\
\hline $\begin{array}{l}\text { Van Wieringen } \\
\text { et al, } \\
2001^{25} \dagger\end{array}$ & 81 & $33.4(10.7)$ & 27 & $\begin{array}{l}\text { Chronic whiplash } \\
\text { syndrome }\end{array}$ & NS & $\begin{array}{l}5 \mathrm{mg} 5 \mathrm{~h} \text { before } \\
\text { individual dim light } \\
\text { melatonin onset time } \\
\text { (oral) }\end{array}$ & $\begin{array}{l}1 \text { tablet/day for } 4 \\
\text { weeks }\end{array}$ & RCT; parallel \\
\hline
\end{tabular}

NS=not specified; RCT=randomised controlled trial.

*Included in efficacy review only; tincluded in safety review only.

( -27.3 to 0.9 ) $\mathrm{min}$; when it was excluded, the point estimate was $-17.4(-26.4$ to -8.4$) \mathrm{min}$. Although the point estimate did not change substantially, the confidence interval narrowed, rendering the result significant.

Not enough studies examined sleep onset latency for publication bias to be tested on the basis of this outcome.
Other efficacy outcomes

Six trials reporting data for sleep efficiency showed a significant effect that favoured melatonin (weighted mean difference 1.9\% $(0.5$ to 3.3$\left.) ; \mathrm{I}^{2}=0 \%\right)^{18}{ }^{20-24}$; however, the effect seems not to be clinically important. The results for other efficacy outcomes are shown in table 4.

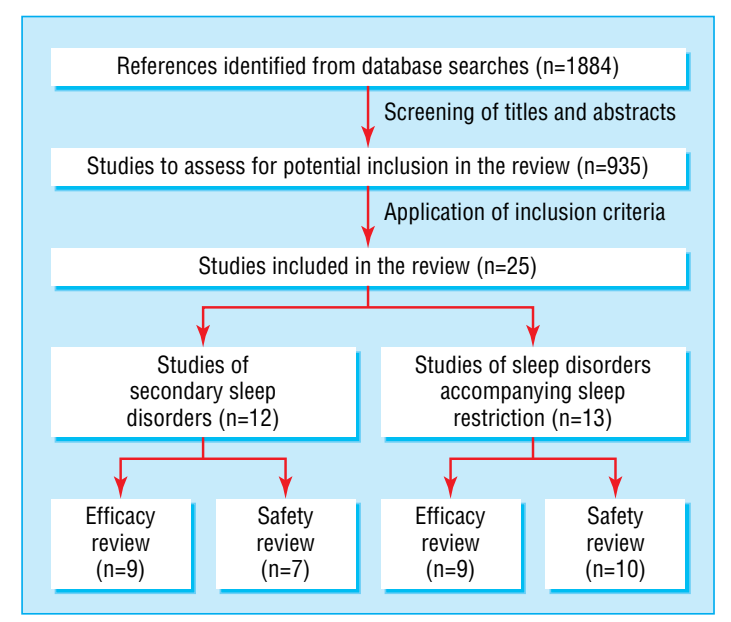

Fig 1 Retrieval and selection of studies of exogenous melatonin in management of secondary sleep disorders and sleep disorders accompanying sleep restriction 


\begin{tabular}{|c|c|c|c|c|c|c|c|}
\hline \multirow[b]{2}{*}{ Study } & \multirow[b]{2}{*}{ Design } & \multirow{2}{*}{$\begin{array}{l}\text { Method of computing SE of } \\
\text { difference between } \\
\text { melatonin and placebo }\end{array}$} & \multicolumn{2}{|r|}{ Melatonin } & \multicolumn{2}{|r|}{ Placebo } & \multirow[b]{2}{*}{ Mean $(95 \% \mathrm{Cl})$ difference } \\
\hline & & & $\begin{array}{l}\text { No in } \\
\text { study }\end{array}$ & Mean (SD) & $\begin{array}{l}\text { No in } \\
\text { study }\end{array}$ & Mean (SD) & \\
\hline $\begin{array}{l}\text { Dodge and Wilson, } \\
2001^{15}\end{array}$ & Crossover & $\begin{array}{l}\text { SDs using estimated } \\
\text { correlation of } 0.5\end{array}$ & 17 & $42(48)$ & 17 & $72(72)$ & $-30.0 \quad(-60.2$ to 0.2$)$ \\
\hline $\begin{array}{l}\text { McArthur and } \\
\text { Budden, } 1998^{18} \\
\end{array}$ & Crossover & $\begin{array}{l}\text { SDs using estimated } \\
\text { correlation of } 0.5\end{array}$ & 9 & $19.1(15.9)$ & 9 & $32.0(25.8)$ & -12.9 (-27.6 to 1.8$)$ \\
\hline $\begin{array}{l}\text { O'Callaghan et al, } \\
1999^{19}\end{array}$ & Crossover & $\begin{array}{l}\text { From exact } P \text { value of } \\
\text { difference }\end{array}$ & 7 & $\begin{array}{l}\text { Not provided: only } \\
\text { difference values were } \\
\text { provided }\end{array}$ & 7 & $\begin{array}{l}\text { Not provided: only difference } \\
\text { values were provided }\end{array}$ & $-23.4(-45.2$ to -1.6$)$ \\
\hline Serfaty et al, $2003^{21}$ & Parallel & $\begin{array}{l}\text { From SDs of change from } \\
\text { baseline scores using a } \\
\text { correlation estimate of } 0.5\end{array}$ & 16 & $\begin{array}{l}\text { Baseline } 39.8(31.2) ; \\
\text { melatonin } 33.3(31.9)\end{array}$ & 15 & $\begin{array}{l}\text { Baseline } 21.9 \text { (17.1); Melatonin } \\
28.9 \text { (24.3) }\end{array}$ & -13.5 (-32.5 to 5.5$)$ \\
\hline Shamir et al, $2000^{22}$ & Crossover & $\begin{array}{l}\text { SDs using estimated } \\
\text { correlation of } 0.5\end{array}$ & 14 & $12.2(7.3)$ & 14 & $6.4(3.8)$ & 5.8 (2.5 to 9.1$)$ \\
\hline Shamir et al, $2000^{23}$ & Crossover & $\begin{array}{l}\text { From exact } P \text { value of } \\
\text { difference }\end{array}$ & 19 & $26.0(25.4)$ & 19 & $46.5(56.0)$ & -20.5 ( -44.4 to 3.4$)$ \\
\hline
\end{tabular}

\section{Safety}

Seven studies were included in the safety analysis ${ }^{15-20}{ }^{25}$; one was non-randomised and six were randomised (table 2). The studies included 164 participants. The quality of these studies was good (median quality index 21 (out of 29); range 20-22). The most commonly reported adverse events were headaches, dizziness, nausea, and drowsiness. The occurrence of these outcomes was similar for melatonin and placebo (table 4).

\section{Sleep restriction}

Efficacy

Table 5 describes the nine trials included in the efficacy analysis for sleep restriction. ${ }^{26-32}$ 295-38 The trials encompassed 427 participants. The median quality score was 4 out of 5 (interquartile range 3-4). Concealment of allocation was unclear in all studies except three, ${ }^{29} 3238$ which had adequate allocation concealment. None of the studies described a funding source.

\section{Sleep onset latency}

Table 6 outlines the mean and standard deviations for sleep onset latency for placebo and melatonin groups for the nine trials that provided data on this outcome..$^{29}{ }^{32}{ }^{35-37}$ The studies produced a combined estimate that favoured melatonin but was not significant (weighted mean difference -1.0 ( -2.3 to 0.3$) \mathrm{min}$; $\left.\mathrm{I}^{2}=4.0 \%\right)($ fig 3$)$.

The results for planned subgroup and sensitivity analyses are in table 7. The subgroups did not differ significantly in any of the categories (all confidence intervals were overlapping, and in all but two cases $(<1 \mathrm{mg}$ dose and parallel study design), results were non-significant ).
Given that the study by Folkard et $\mathrm{al}^{29}$ was allotted a high proportion of weight in the primary analysis but had a small sample size, we conducted a post hoc sensitivity analysis excluding this study. When the Folkard study was excluded from the analysis, there was almost no change in the point estimate and the confidence interval widened slightly: $(-1.03(-3.59$ to 1.53$)$ min when excluded $v-0.97$ ( -2.26 to 0.33 ) $\mathrm{min}$ ).

The funnel plot for sleep onset latency showed no obvious signs of asymmetry. There were also no indications of publication bias with Begg's test $(\mathrm{P}=0.35 ; \mathrm{n}=9)$; Egger's test $(\mathrm{P}=0.48)$; and Duval's trim and fill method (no new studies added).

\section{Other efficacy outcomes}

For sleep efficiency, the combined estimate from five trials ${ }^{26}$ 30-32 37 showed no significant difference between melatonin and placebo (weighted mean difference $0.5 \%$ ( -0.6 to 1.6$) ; \mathrm{I}^{2}=20.9 \%$ ). The results for other efficacy outcomes are in table 7 .

Safety

Of the 10 studies included in the safety analysis, ${ }^{27} 28$ 30-36 38 all studies but one ${ }^{28}$ were randomised controlled trials (table 5). The studies included 487 participants. The methodological quality of these studies was good (median quality index 21 (out of 29); range 20-22). The most commonly reported adverse events were headache, dizziness, nausea, and drowsiness. The occurrence of these outcomes did not differ significantly for melatonin versus placebo (table 7).

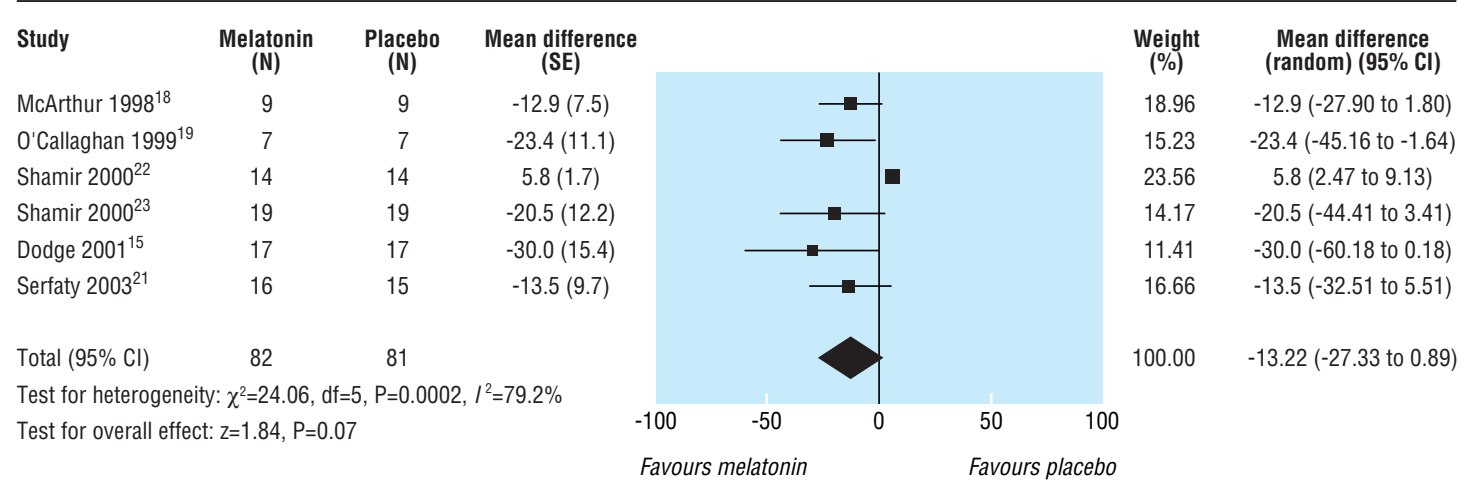

Fig 2 Sleep onset latency in people with secondary sleep disorders 
Table 4 Efficacy and safety outcomes and subgroup and sensitivity analyses for trials of melatonin in people with secondary sleep disorders

\begin{tabular}{|c|c|c|c|c|c|}
\hline Outcome & No of studies & Melatonin group & Placebo group & $\begin{array}{l}\text { Summary } \\
\text { measure }\end{array}$ & Point estimate $(95 \% \mathrm{Cl})$ \\
\hline \multicolumn{6}{|l|}{ Efficacy } \\
\hline Sleep onset latency (min) & 6 & 82 & 81 & WMD & $-13.2(-27.3$ to 0.9$)$ \\
\hline Sleep efficiency (\%) & 6 & 187 & 129 & WMD & 1.9 (0.5 to 3.3$)$ \\
\hline Wakefulness after sleep onset (min) & 3 & 137 & 80 & WMD & $-6.3(-16.6$ to 3.9$)$ \\
\hline Total sleep time (min) & 9 & 220 & 162 & WMD & 15.6 (7.2 to 24.0$)$ \\
\hline REM sleep (\%) & 1 & 14 & 14 & WMD & $-1.5(-4.4$ to 1.4$)$ \\
\hline \multicolumn{6}{|l|}{ Adverse events } \\
\hline Headaches & 7 & 127 & 126 & $\mathrm{RD}$ & $0.02(-0.03$ to 0.07$)$ \\
\hline Dizziness & 7 & 127 & 126 & $\mathrm{RD}$ & $0(-0.03$ to 0.03$)$ \\
\hline Nausea & 7 & 127 & 126 & $\mathrm{RD}$ & 0 (-0.03 to 0.03$)$ \\
\hline Drowsiness & 7 & 127 & 126 & $\mathrm{RD}$ & $0(-0.03$ to 0.03$)$ \\
\hline \multicolumn{6}{|c|}{ Subgroup and sensitivity analyses of sleep onset latency } \\
\hline \multicolumn{6}{|l|}{ Age (years) ${ }^{\star}$ : } \\
\hline Children (0-18) & 3 & 33 & 33 & WMD & $-18.1(-29.4$ to -6.8$)$ \\
\hline Adults (19-65) & 3 & 49 & 48 & WMD & $-6.6(-24.6$ to 11.4$)$ \\
\hline \multicolumn{6}{|l|}{ Co-morbidity*: } \\
\hline Rett syndrome & 1 & 9 & 9 & WMD & $-12.9(-27.6$ to 1.8$)$ \\
\hline Tuberous sclerosis & 1 & 7 & 7 & WMD & $-23.4(-45.2$ to -1.6$)$ \\
\hline Developmental disabilities & 1 & 17 & 17 & WMD & $-30.0(-60.2$ to 0.2$)$ \\
\hline Depression & 1 & 16 & 15 & WMD & $-13.5(-32.5$ to 5.5$)$ \\
\hline Schizophrenia & 2 & 33 & 33 & WMD & $-4.6(-29.8$ to 20.6$)$ \\
\hline \multicolumn{6}{|l|}{ Dosage $(\mathrm{mg})$ : } \\
\hline $1-3$ & 2 & 33 & 33 & WMD & -4.6 (-29.8 to 20.6) \\
\hline $4-5$ & 1 & 7 & 7 & WMD & $-23.4(-45.2$ to -1.6$)$ \\
\hline $6-10$ & 1 & 16 & 15 & WMD & -13.5 (-32.5 to 5.5$)$ \\
\hline \multicolumn{6}{|l|}{ Duration (weeks)*: } \\
\hline $1-2$ & 2 & 24 & 24 & WMD & $-25.7(-43.3$ to -8.0$)$ \\
\hline $3-4$ & 2 & 33 & 33 & WMD & -4.6 (-29.8 to 20.6) \\
\hline$>4$ & 2 & 25 & 24 & WMD & $-13.1(-24.8$ to -1.5$)$ \\
\hline \multicolumn{6}{|l|}{ Measurement method ${ }^{*}$ : } \\
\hline Polysomnography & 1 & 14 & 14 & WMD & 5.8 (2.5 to 9.1$)$ \\
\hline Actigraphy & 3 & 44 & 43 & WMD & $-14.5(-25.0$ to -4.1$)$ \\
\hline Questionnaire & 2 & 24 & 24 & WMD & $-25.7(-43.3$ to -8.0$)$ \\
\hline \multicolumn{6}{|l|}{ Study design: } \\
\hline $\begin{array}{c}\text { Parallel } \\
\end{array}$ & 1 & 16 & 15 & WMD & $-13.5(-32.5$ to 5.5$)$ \\
\hline Crossover & 5 & 66 & 66 & WMD & -13.5 (-29.7 to 2.8) \\
\hline \multicolumn{6}{|l|}{ Allocation concealment*: } \\
\hline Unclear & 5 & 68 & 67 & WMD & $-17.4(-26.4$ to -8.4$)$ \\
\hline Adequate & 1 & 14 & 14 & WMD & 5.8 (2.5 to 9.1$)$ \\
\hline
\end{tabular}

$\mathrm{WMD}=$ weighted mean difference; $\mathrm{RD}=$ risk difference

${ }^{*} \mathrm{P}<0.001$, Deeks $\chi^{2}$ test.

\section{Discussion}

This review of the effects of exogenous melatonin on people with secondary sleep disorders or sleep disorders accompanying sleep restriction showed that melatonin does not have a significant effect on sleep onset latency in either disorder or on sleep efficiency in people with sleep disorders accompanying sleep restriction. Although the increase in sleep efficiency in people with secondary sleep disorders was statistically significant with melatonin, the effect was small-1.9\%-an increase of less than 10 minutes in the amount of time spent asleep for eight hours spent in bed. On the basis of advice from clinical sleep experts, we considered this effect to be clinically unimportant, due to its small magnitude.

\section{Factors affecting heterogeneity}

The effect of melatonin on sleep onset latency in studies of people with secondary sleep disorders was associated with substantial heterogeneity, which seemed to be highly influenced by the study by Shamir et al. ${ }^{23}$ This study was unique in that polysomnography was used to assess sleep outcomes and the method of concealing treatment allocation was reported and adequate. Although the estimation of sleep variables differs according to the assessment tool used to measure them, ${ }^{39}$ the heterogeneity in results across studies is unlikely to be due to variation in assessment tool, as any differences between methods would have been cancelled out when absolute differences in the effect of treatment and placebo were obtained.

Regarding the effect of allocation concealment on effect estimates, failure to conceal treatment allocation adequately is associated with larger effect estimates. ${ }^{5}{ }^{40}$ Allocation concealment may have been inadequate in the studies for which the adequacy of allocation concealment was unclear, which would tend to result in overestimation of treatment effect. Also, the heterogeneity across studies may have been due to publication or reporting bias, such that small studies with negative results were not published and therefore under-represented in the analysis; as this category included only nine studies, we could not verify this bias.

Other factors may have contributed to heterogeneity in results across studies of secondary sleep disorders. Formulations of melatonin vary in quality. In studies that reported details of the intervention, the rate of release of melatonin varied from slow to 
Table 5 Characteristics of trials of people with sleep disorders accompanying sleep restriction

\begin{tabular}{|c|c|c|c|c|c|c|c|c|}
\hline \multirow[b]{2}{*}{ Study and year } & \multirow[b]{2}{*}{$\begin{array}{l}\text { No enrolled } \\
\text { (analysed) }\end{array}$} & \multirow[b]{2}{*}{$\begin{array}{l}\text { Mean (SD or range) } \\
\text { age (years) }\end{array}$} & \multirow[b]{2}{*}{$\%$ male } & \multirow[b]{2}{*}{ Disorder } & \multicolumn{3}{|c|}{ Intervention } & \multirow[b]{2}{*}{ Design } \\
\hline & & & & & Formulation & Dosage and timing (route) & $\begin{array}{l}\text { Frequency and } \\
\text { duration }\end{array}$ & \\
\hline $\begin{array}{l}\text { Beaumont et al, } \\
2004^{26 \star}\end{array}$ & $27(18)$ & $35.3(8.1)$ & 67 & Jet lag & NS & $\begin{array}{l}5 \mathrm{mg} \text { on day }-1 \text { at } 1700 ; \text { on day } 0 \\
\text { at } 1600 \text {; on day } 1 \text { to day } 3 \text { at } \\
2300 \text { (NS) }\end{array}$ & $5 \mathrm{mg} /$ day for 5 days & RCT; parallel \\
\hline $\begin{array}{l}\text { Claustrat et al, } \\
1992^{27 \dagger}\end{array}$ & $37(15)$ & $\begin{array}{l}\text { Melatonin } 36.3(8.9) \\
\text { placebo: } 35.7(6.4)\end{array}$ & $\begin{array}{l}\text { Melatonin } \\
\text { 53; placebo } \\
67\end{array}$ & Jet lag & NS & $8 \mathrm{mg}$ at 2200 (oral) & $\begin{array}{l}1 \text { capsule/day for } 4 \\
\text { days }\end{array}$ & RCT; parallel \\
\hline $\begin{array}{l}\text { Edwards et al, } \\
2000^{28 \dagger}\end{array}$ & 31 & $\begin{array}{l}\text { Melatonin } 40(13) \\
\text { placebo } 41(12)\end{array}$ & $\begin{array}{l}\text { Melatonin } \\
\text { 93; placebo } \\
88\end{array}$ & Jet lag & NS & $\begin{array}{l}5 \mathrm{mg} \text { taken on plane between } \\
1800 \text { to } 1900 \text { and between } 2200 \\
\text { to } 2300 \text {, according to local time at } \\
\text { destination and for next } 3 \\
\text { evenings }\end{array}$ & $\begin{array}{l}2 \text { capsules/day for } \\
\text { first day and then } 1 \\
\text { capsule/day for } 3 \\
\text { days }\end{array}$ & $\begin{array}{l}\text { non-RCT; } \\
\text { parallel }\end{array}$ \\
\hline $\begin{array}{l}\text { Folkard et al, } \\
1993^{29 *}\end{array}$ & $17(7)$ & $29(7)$ & 88 & $\begin{array}{l}\text { Shiftwork } \\
\text { disorder }\end{array}$ & NS & $5 \mathrm{mg}$ at $0642 \pm 7.6 \mathrm{~min}$ (oral) & $\begin{array}{l}1 \text { capsule/day for } 6 \\
\text { successive day } \\
\text { sleeps taken between } \\
\text { night shifts }\end{array}$ & $\begin{array}{l}\text { RCT; } \\
\text { crossover }\end{array}$ \\
\hline $\begin{array}{l}\text { James et al, } \\
1998^{30}\end{array}$ & $24(22)$ & $29(8)$ & 77 & $\begin{array}{l}\text { Shiftwork } \\
\text { disorder }\end{array}$ & NS & $\begin{array}{l}6 \mathrm{mg} 0.5 \mathrm{~h} \text { before each } \\
\text { consecutive day sleep (oral) }\end{array}$ & $\begin{array}{l}6 \mathrm{mg} / \text { day for } 4 \\
\text { treatment cycles } \\
\text { lasting } 4 \text { to } 6 \\
\text { consecutive night } \\
\text { shifts }\end{array}$ & $\begin{array}{l}\text { RCT; } \\
\text { crossover }\end{array}$ \\
\hline $\begin{array}{l}\text { Jockovich et al, } \\
2000^{31}\end{array}$ & 19 & 28.2 (NS) & 21 & $\begin{array}{l}\text { Shiftwork } \\
\text { disorder }\end{array}$ & NS & $\begin{array}{l}1 \mathrm{mg} 0.5 \text { to } 1 \mathrm{~h} \text { before daytime } \\
\text { sleep (oral) }\end{array}$ & $\begin{array}{l}1 \text { caplet/day for } 3 \\
\text { consecutive days }\end{array}$ & $\begin{array}{l}\text { RCT; } \\
\text { crossover }\end{array}$ \\
\hline $\begin{array}{l}\text { Jorgensen and } \\
\text { Witting, } \\
1998^{32}\end{array}$ & $20(18)$ & 32 (25 to 40$)$ & 89 & $\begin{array}{l}\text { Shiftwork } \\
\text { disorder }\end{array}$ & NS & $\begin{array}{l}10 \mathrm{mg} \text { morning after each night } \\
\text { shift (oral) }\end{array}$ & $\begin{array}{l}1 \text { tablet/day for } \\
\text { varied amount of } \\
\text { time }\end{array}$ & $\begin{array}{l}\text { RCT; } \\
\text { crossover }\end{array}$ \\
\hline $\begin{array}{l}\text { Petrie et al, } \\
1988^{33 \dagger}\end{array}$ & $20(15)$ & NS (28 to 68$)$ & 60 & Jet lag & NS & $\begin{array}{l}5 \mathrm{mg} \text { taken between } 1000 \text { and } \\
1200 \text { local time; also taken at the } \\
\text { same time during the flight and } \\
\text { between } 2200 \text { and } 2400 \\
\text { (destination time) after arrival (NS) }\end{array}$ & $\begin{array}{l}1 \text { dose for } 3 \text { days } \\
\text { before flight, } 1 \text { dose } \\
\text { during flight, and } 1 \\
\text { dose/day for } 3 \text { days } \\
\text { after arrival }\end{array}$ & $\begin{array}{l}\text { RCT; } \\
\text { crossover }\end{array}$ \\
\hline $\begin{array}{l}\text { Petrie et al, } \\
1993^{34 \dagger}\end{array}$ & $52(44)$ & $34.9(7.7)$ & 50 & Jet lag & NS & $5 \mathrm{mg}$ taken between 0700 to 0800 & $\begin{array}{l}5 \mathrm{mg} \text { early melatonin } \\
\text { for } 8 \text { days, } 5 \mathrm{mg} \text { late } \\
\text { melatonin for } 5 \text { days }\end{array}$ & RCT; parallel \\
\hline $\begin{array}{l}\text { Suhner et al, } \\
1998^{35}\end{array}$ & $320(234)$ & 20 to 65 & 54 & Jet lag & $\begin{array}{l}\text { Fast release and } \\
\text { controlled release }\end{array}$ & $\begin{array}{l}0.5 \mathrm{mg} \text { fast release, } 5 \mathrm{mg} \text { fast } \\
\text { release, or } 2 \mathrm{mg} \text { controlled release } \\
\text { melatonin on first day after flight } \\
\text { at } 2310 \text { and on subsequent days } \\
\text { at } 2329 \text { (NS) }\end{array}$ & $\begin{array}{l}1 \text { dose/day for } 4 \\
\text { days after eastward } \\
\text { flight }\end{array}$ & RCT; parallel \\
\hline $\begin{array}{l}\text { Suhner et al, } \\
2001^{36}\end{array}$ & $160(74)$ & 41.3 (18 to 68$)$ & 51 & Jet lag & NS & $\begin{array}{l}5 \mathrm{mg} \text { taken on return flight } \\
\text { (eastbound) between } 1700 \text { and } \\
2100 \text { local time at the place of } \\
\text { departure depending on flight } \\
\text { schedule (NS) }\end{array}$ & $\begin{array}{l}1 \text { dose/day on return } \\
\text { flight and for } 4 \\
\text { consecutive days } \\
\text { after flight }\end{array}$ & RCT; parallel \\
\hline $\begin{array}{l}\text { Waldhauser et } \\
\text { al, } 1990^{37 \star}\end{array}$ & $20(20)$ & $26.4(4.8)$ & 50 & $\begin{array}{l}\text { Induced } \\
\text { insomnia }\end{array}$ & NS & $80 \mathrm{mg}$ at 2100 (oral) & Single dose & RCT; parallel \\
\hline $\begin{array}{l}\text { Wright et al, } \\
1998^{38}\end{array}$ & $20(15)$ & 38.6 (32 to 45$)$ & 80 & $\begin{array}{l}\text { Shiftwork } \\
\text { disorder }\end{array}$ & NS & $\begin{array}{l}5 \mathrm{mg} 30 \mathrm{~min} \text { before bedtime in } \\
\text { the evening (oral) }\end{array}$ & $\begin{array}{l}5 \mathrm{mg} / \mathrm{night} \text { for } 3 \\
\text { nights following shift } \\
\text { work }\end{array}$ & $\begin{array}{l}\text { RCT; } \\
\text { crossover }\end{array}$ \\
\hline
\end{tabular}

NS=not specified

*Included in efficacy review only; tincluded in safety review only.

fast, a range of doses was used, and the duration of administration varied from days to weeks. Indeed, our results show that dosage and duration of melatonin administration explain a considerable amount of heterogeneity across studies.

Two other systematic reviews examining the use of melatonin for jet lag concluded that melatonin is effective in alleviating the symptoms of jet lag. ${ }^{41}{ }^{42}$ These reviews examined the effect of melatonin on both the daytime fatigue and the sleep disturbance aspects of jet lag. Our review shows that melatonin does not affect either sleep onset latency or sleep efficiency in people with jet lag or people with shiftwork disorder. Our results do not provide evidence that melatonin is effective in alleviating sleep disturbance in jet lag, but we did not determine the effect of melatonin on measures of daytime fatigue.

\section{Other limitations}

The observations of this review are based mostly on studies with relatively short durations, so the efficacy and safety of melatonin reported here may reflect only its short term effects. Secondly, several studies did not report adequately on details of the intervention, such as content, quality, and formulation of the melatonin product under study, nor on methods of allocation concealment or source of funding, which casts doubt on the methodological quality of these studies, despite a good median Jadad score or Downs and Black quality index. Thirdly, non-English language reports were excluded from the review; however, we did not find strong evidence of publication bias, so it is unlikely that the inclusion of these reports would have altered our findings substantially.

We thank the National Centre for Complementary and Alternative Medicine, National Institutes of Health for sponsoring this research, through the Agency for Healthcare Research and Quality. We are grateful to members of our technical expert panel for providing input on the direction and scope of the review. We are especially grateful to Manisha Witmans for her input on the manuscript.

Contributors: NB planned, oversaw, and participated in all steps of the systematic review process and in writing and editing the manuscript. BV performed all statistical analyses and participated in writing and editing the 
Research

\begin{tabular}{|c|c|c|c|c|c|c|c|}
\hline \multirow{2}{*}{ Study } & \multirow{2}{*}{ Design } & \multirow{2}{*}{$\begin{array}{l}\text { Method of computing SE of } \\
\text { difference between melatonin } \\
\text { and placebo }\end{array}$} & \multicolumn{2}{|r|}{ Melatonin } & \multicolumn{2}{|r|}{ Placebo } & \multirow[b]{2}{*}{ Mean $(95 \% \mathrm{CI})$ difference } \\
\hline & & & No & Mean (SD) & No & Mean (SD) & \\
\hline $\begin{array}{l}\text { Beaumont et al, } \\
2004^{26}\end{array}$ & Parallel & From SDs & 9 & $29.7(14.0)$ & 9 & $32.2(14.3)$ & $-2.6(-15.7$ to 10.5$)$ \\
\hline $\begin{array}{l}\text { Folkard et al, } \\
1993^{29}\end{array}$ & Crossover & $\begin{array}{l}\text { SDs using estimated } \\
\text { correlation of } 0.5\end{array}$ & 7 & $4.5(1.6)$ & 7 & $5.6(1.8)$ & $-1.1 \quad(-2.3$ to 0.2$)$ \\
\hline James et al, $1998^{30}$ & Crossover & $\begin{array}{l}\text { From exact } P \text { value of } \\
\text { difference }\end{array}$ & 22 & $15(7.0)$ & 22 & $16(9.0)$ & $-1.0(-5.7$ to 3.7$)$ \\
\hline $\begin{array}{l}\text { Jockovich et al, } \\
2000^{31}\end{array}$ & Crossover & $\begin{array}{l}\text { From exact } P \text { value of } \\
\text { difference }\end{array}$ & 19 & 7.6 (not provided) & 19 & 6.8 (not provided) & 0.8 (-2.7 to 4.3$)$ \\
\hline $\begin{array}{l}\text { Jorgensen and } \\
\text { Witting, } 1998^{32}\end{array}$ & Crossover & $\begin{array}{l}\text { From confidence interval of } \\
\text { difference }\end{array}$ & 18 & 13.6 (not provided) & 18 & 15.6 (not provided) & $-2.0(-7.5$ to 3.5$)$ \\
\hline $\begin{array}{l}\text { Suhner et al, } \\
1998^{35}\end{array}$ & Parallel & $\begin{array}{l}\text { Estimated from upper bound } \\
\text { of } P \text { value }\end{array}$ & 174 & 19.4 (not provided) & 60 & 32.1 (not provided) & $-12.6(-25.2$ to -0.1$)$ \\
\hline $\begin{array}{l}\text { Suhner et al, } \\
2001^{36}\end{array}$ & Parallel & From SDs & 35 & $21.7(23.7)$ & 39 & $21.2(27.3)$ & $0.5(-11.1$ to 12.1$)$ \\
\hline $\begin{array}{l}\text { Waldhauser et al, } \\
1990^{37}\end{array}$ & Parallel & $\begin{array}{l}\text { Estimated from upper bound } \\
\text { of } P \text { value }\end{array}$ & 10 & 14.7 (not provided) & 10 & 23.7 (not provided) & $-9.0(-19.2$ to 1.2$)$ \\
\hline Wright et al, $1998^{38}$ & Crossover & $\begin{array}{l}\text { SDs using estimated } \\
\text { correlation of } 0.5 .\end{array}$ & 15 & $22.3(14.2)$ & 15 & $19.0(13.7)$ & $3.3(-3.8$ to 10.4$)$ \\
\hline
\end{tabular}

manuscript. NH participated in most steps of the systematic review process and in writing and editing the manuscript. RP participated in all steps of the systematic review process and reviewed the manuscript. LT conducted the literature search, provided technological expertise for the inclusion process, and participated in editing the manuscript. LH participated in writing the proposal, provided methodological expertise, and participated in writing and editing the manuscript. SV participated in writing the proposal, provided methodological and content expertise, and participated in editing the manuscript. TK participated in writing the proposal, provided methodological expertise, and provided feedback on the manuscript. GB participated in writing the proposal, provided content expertise, and participated in writing and editing the manuscript. Michelle Tubman, Mia Lang, Maria Ospina, Victor Juorio, and Ellen Crumley were involved in study selection, quality assessment, and data extraction or entry. TK is guarantor.

Funding: This study was conducted under contract to the Agency for Healthcare Research and Quality (contract No 290-02-0023), Rockville, MD, and support from the National Center for Complementary and Alternative Medicine, National Institutes of Health, Bethesda, MD. SV is supported by Agency for Healthcare Research and Quality (AHRQ), USA; Canadian Institutes of Health Research; Change Foundation; Department of Pediatrics; National Health Products Directorate, Health Canada; Ontario Mental Health Foundation; Stollery Children's Hospital and Foundation; The Hospital for Sick Children Foundation; and the University of Alberta. GB is supported by AHRQ; Canadian Institutes of Health Research; Canada Research Chairs Program; Stanley Foundation; University of Alberta Hospital Foundation; Bebensee Schizophrenia Research Fund; Davey Endowment; and Zyprexa Research Foundation. The authors of this article are responsible for its contents, including any clinical or treatment recommendations. No statement in this article should be construed as an official position of the Agency for Healthcare Research and Quality, the National Center for Complementary and Alternative Medicine or the US Department of Health and Human Services.

Competing interests: None declared.

Ethical approval: Not required.

1 National Institutes of Health. National Center on Sleep Disorders Research Plan. 2003. www.nhlbi.nih.gov/health/prof/sleep/res_plan/sleep-rplan.pdf (accessed 14 Jan 2006)

2 Roller L. Treating sleep disorders. Austral J Pharm 2002;83:443-7.

3 Reiter RJ. Melatonin: clinical relevance. Best Pract Res Clin Endocrinol Metab 2003;17:273-85.

4 Jadad AR, Moore RA, Carroll D, Jenkinson C, Reynolds DJ, Gavaghan DJ, et al. . Assessing the quality of reports of randomized clinical trials: is blinding necessary? Controlled Clin Trials 1996;17:1-12.

5 Schulz KF, Chalmers I, Hayes RJ, Altman D. Empirical evidence of bias. Dimensions of methodological quality associated with estimates of treatment effects in controlled trials. JAMA 1995:273:408-12.

6 Downs SH, Black N. The feasibility of creating a checklist for the assessment of the methodological quality both of randomized and non-randomized studies of health care interventions. J Epidemiol Commun Health 1998;52:377-84.

7 Sutton AJ, Abrams KR, Jones DR, Sheldon TA, Song F. Methods for meta-analysis in medical research. Chichester: Wiley, 2000:58.

8 Elbourne DR, Altman DG, Higgins JPT, Curtin F, Worthington HV, Vail A. Meta-analyses involving cross-over trials. Int Jt Epidemiolt 2002;31:140-9.

9 Higgins JPT, Thompson SG. Quantifying heterogeneity in a meta-analysis. Stat Med $2002 \cdot 21 \cdot 1539-58$.

10 Deeks IJ, Altman DG, Bradburn MJ. Statistical methods for examining heterogeneity and combining results from several studies in meta-analysis. In: Eggar M, Smith GD, Altman DG, eds. Systematic reviews in health care:meta-analysis in context. 3rd ed. London BMJ Publishing Group, 2001:285-312.

11 Begg CB, Mazumdar M. Operating characteristics of a rank correlation test for publication bias. Biometrics 1994;50:1088-101.

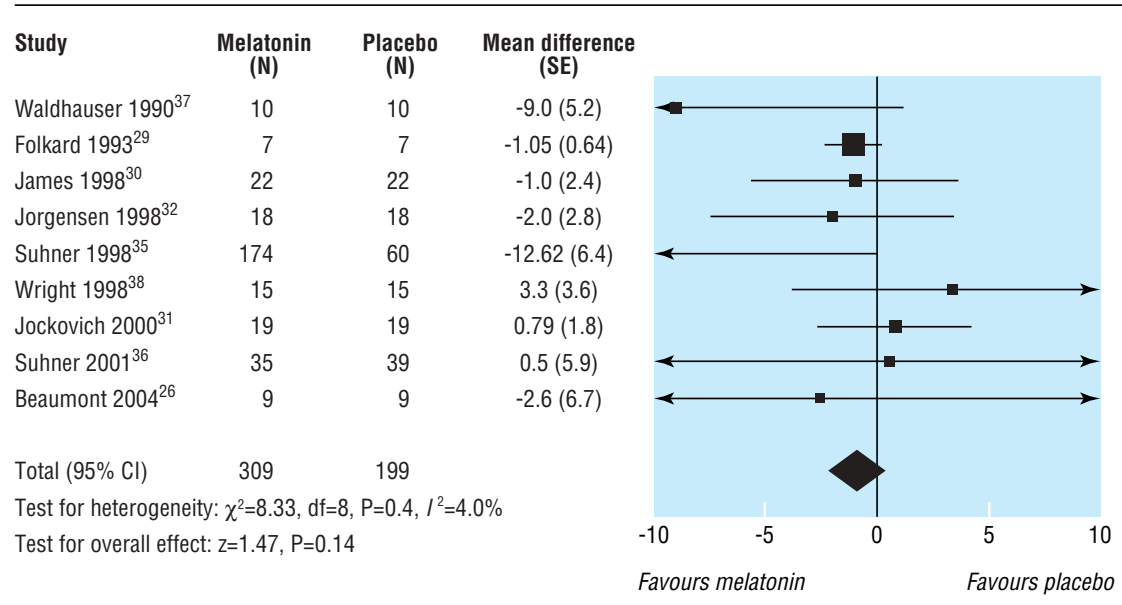

$\begin{array}{cc}\begin{array}{c}\text { Weight } \\ (\%)\end{array} & \begin{array}{c}\text { Mean difference } \\ \text { (random) }(95 \% \text { CI) }\end{array} \\ 1.60 & -9.00(-19.19 \text { to } 1.19) \\ 66.62 & -1.05(-2.30 \text { to } 0.20) \\ 7.27 & -1.00(-5.70 \text { to } 3.70) \\ 5.40 & -2.00(-7.49 \text { to } 3.49) \\ 1.06 & -12.62(-25.16 \text { to }-0.08) \\ 3.31 & 3.30(-3.76 \text { to } 10.36) \\ 12.53 & 0.79(-2.74 \text { to } 4.32) \\ 1.25 & 0.50(-11.06 \text { to } 12.06) \\ 0.97 & -2.60(-15.73 \text { to } 10.53)\end{array}$

$100.00-0.97(-2.26$ to 0.33$)$

Fig 3 Sleep onset latency in people with sleep disorders accompanying sleep restriction 
Table 7 Efficacy and safety outcomes and subgroup and sensitivity analyses for trials of people with sleep disorders accompanying sleep restriction

\begin{tabular}{|c|c|c|c|c|c|}
\hline Outcome & No of studies & $\begin{array}{c}\text { No in melatonin } \\
\text { group }\end{array}$ & $\begin{array}{l}\text { No in placebo } \\
\text { group }\end{array}$ & Summary measure & Point estimate (95\% Cl) \\
\hline \multicolumn{6}{|l|}{ Efficacy } \\
\hline Sleep onset latency (min) & 9 & 309 & 199 & WMD & $-1.0(-2.3$ to 0.3$)$ \\
\hline Sleep efficiency $(\%)$ & 5 & 78 & 78 & WMD & $0.5(-0.6$ to 1.6$)$ \\
\hline Sleep quality (SD) & 5 & 248 & 138 & SMD & $0.2(-0.2$ to 0.6$)$ \\
\hline Wakefulness after sleep onset (min) & 2 & 44 & 48 & WMD & $-10.4(-21.0$ to 0.2$)$ \\
\hline Total sleep time (min) & 7 & 100 & 100 & WMD & 18.2 (8.1 to 28.3) \\
\hline$\%$ REM sleep & 1 & 10 & 10 & WMD & $-3.6(-7.3$ to 0.1$)$ \\
\hline \multicolumn{6}{|l|}{ Adverse events } \\
\hline Headaches & 9 & 342 & 218 & $\mathrm{RD}$ & $-0.01(-0.05$ to 0.02$)$ \\
\hline Dizziness & 9 & 342 & 218 & $\mathrm{RD}$ & $0.00(-0.03$ to 0.03$)$ \\
\hline Nausea & 10 & 356 & 235 & $\mathrm{RD}$ & $0.00(-0.03$ to 0.02$)$ \\
\hline Drowsiness & 10 & 356 & 235 & $\mathrm{RD}$ & $0.00(-0.03$ to 0.03$)$ \\
\hline \multicolumn{6}{|c|}{ Subgroup and sensitivity analyses of sleep onset latency } \\
\hline \multicolumn{6}{|c|}{ Dosage $^{*}:$} \\
\hline$<1 \mathrm{mg}$ & 1 & 58 & 60 & WMD & $-11.8(-23.6$ to -0.0$)$ \\
\hline $1-3 \mathrm{mg}$ & 2 & 77 & 79 & WMD & $-4.5(-17.3$ to 8.3$)$ \\
\hline $4-5 \mathrm{mg}$ & 5 & 124 & 130 & WMD & $-1.0(-4.0$ to 2.1$)$ \\
\hline $10-20 \mathrm{mg}$ & 1 & 18 & 18 & WMD & $-2.0(-7.5$ to 3.5$)$ \\
\hline \multicolumn{6}{|l|}{ Type of sleep disorder: } \\
\hline Jet lag & 3 & 218 & 108 & WMD & $-4.7(-12.6$ to 3.1$)$ \\
\hline Shiftwork & 5 & 81 & 81 & WMD & $-0.8(-1.9$ to 0.3$)$ \\
\hline Deprivation & 1 & 10 & 10 & WMD & $-9.0(-19.2$ to 1.2$)$ \\
\hline \multicolumn{6}{|l|}{ Study design: } \\
\hline $\begin{array}{c}\text { Parallel } \\
\end{array}$ & 4 & 228 & 118 & WMD & $-6.1(-11.9$ to -0.2$)$ \\
\hline Crossover & 5 & 81 & 81 & WMD & -0.8 (-1.9 to 0.3$)$ \\
\hline \multicolumn{6}{|l|}{ Quality: } \\
\hline High (Jadad score 4-5) & 5 & 264 & 154 & WMD & $-1.2(-4.6$ to 2.3$)$ \\
\hline Moderate (Jadad score 2-3) & 4 & 45 & 45 & WMD & $-0.9(-2.7$ to 0.8$)$ \\
\hline \multicolumn{6}{|l|}{ Allocation concealment: } \\
\hline Unclear & 6 & 254 & 144 & WMD & $-1.4(-3.8$ to 1.1$)$ \\
\hline Adequate & 3 & 55 & 55 & WMD & $-0.5(-3.7$ to 2.7$)$ \\
\hline
\end{tabular}

$\mathrm{WMD}=$ weighted mean difference; $\mathrm{SMD}=$ standardised mean difference; $\mathrm{RD}=$ risk difference.

${ }^{*}$ No studies with 6-9 $\mathrm{mg}$ dose range.

12 Egger M, Smith GD, Schneider M, Minder C. Bias in meta-analysis detected by a single graphical test. $B M J 1997 ; 315: 629-34$.

13 Duval S, Tweedie R. A nonparametric "trim and fill" method of accounting for publicaDuval S, Tweedie R. A nonparametric "trim and fil"
tion bias in meta-analysis. JAMA 2000;95:89-98.

14 Camfield P, Gordon K, Dooley J, Camfield C. Melatonin appears ineffective in children with intellectual deficits and fragmented sleep: six " $\mathrm{N}$ of 1" trials. $J$ Child Neurol 1996;11:341-3.

15 Dodge NN, Wilson GA. Melatonin for treatment of sleep disorders in children with developmental disabilities. J Child Neurol 2001;16:581-4.

16 Jan J, Espezel H, Appleton R. The treatment of sleep disorders with melatonin. Develop Med Child Neurol 1994;36:97-107.

17 Jean-Louis G, von Gizycki H, Zizi F. Melatonin effects on sleep, mood, and cognition in elderly with mild cognitive impairment. J Pineal Res 1998;25:177-83.

\section{What is already known on this topic}

Sleep disorders are a widespread problem and place a burden on society through their negative impact on quality of life, safety, productivity, and healthcare utilisation

Complementary and alternative therapies, such as melatonin, have been used increasingly to manage sleep disorders

\section{What this study adds}

There is no evidence that melatonin is effective in treating secondary sleep disorders or sleep disorders accompanying sleep restriction, such as jet lag or shiftwork disorder

There is evidence that melatonin is safe with short term use, but additional studies are needed to determine its long term safety

18 McArthur AJ, Budden SS. Sleep dysfunction in Rett syndrome: a trial of exogenous melatonin treatment. Developmental Med Child Neurol 1998;40:186-92.

19 O'Callaghan FJK, Clarke AA, Hancock E, Hunt A, Osborne JP. Use of melatonin to treat sleep disorders in tuberous sclerosis. Developmental Med Child Neurol 1999;41:123-6.

20 Serfaty M, Kennell-Webb S, Warner J, Blizard R, Raven, P. Double blind randomised placebo-controlled trial of low dose melatonin for sleep disorders in dementia. Int J Geriatr Psychiatry 2002;17:1120-7.

21 Serfaty MA, Osborne D, Buszewicz MJ, Raven PW. The effects of exogenous melatonin in major depression. Biol Med Rhythm Res 2003:1191-3.

22 Shamir E, Laudon M, Barak Y, Anis Y, Rotenberg V, Elizur A, et al. Melatonin improves sleep quality of patients with chronic schizophrenia.J Clin Psychiatry 2000;61:373-7.

23 Shamir E, Rotenberg VS, Laudon M, Zisapel N, Elizur A. First-night effect of melatonin treatment in patients with chronic schizophrenia. J Clin Psychopharmacol 2000;20:691-4.

24 Singer C, Tractenberg RE, Kaye J, Schafer K, Gamst A, Grundman M, et al. A multicenter, placebo-controlled trial of melatonin for sleep disturbance in Alzheimer's disease. Sleep 2003;26:893-901

25 Van Wieringen S, Jansen T, Smits MG, Nagtegaal JE, Coenen AML. Melatonin for chronic whiplash syndrome with delayed melatonin onset. Clin Drug Invest 2001;21:813-20

26 Beaumont M, Batejat D, Pierard C, Van Beers P, Denis JB, Coste O, et al. Caffeine or melatonin effects on sleep and sleepiness after rapid eastward transmeridian travel. $J$ Appl Physiol 2004;96:50-8.

27 Claustrat B, Brun J, David M, Sassolas G, Chazot G. Melatonin and jet lag: confirmatory result using a simplified protocol. Biol Psychiatry 1992;32:705-11.

28 Edwards BJ, Atkinson G, Waterhouse J, Reilly T, Godfrey R, Budgett R. Use of melatonin in recovery from jet-lag following an eastward flight across 10 time-zones. Ergonomics 2000;43:1501-3.

29 Folkard S, Arendt J, Clark M. Can melatonin improve shift workers' tolerance of the night shift? Some preliminary findings. Chronobiol 1993;10:315-20.

30 James M, Tremea MO, Jones JS, Krohmer JR. Can melatonin improve adaptation to night shift? Am J Emerg Med 1998;16:1-7.

31 Jockovich M, Cosentino D, Cosentino L, Wears RL, Seaberg DC. Effect of exogenous melatonin on mood and sleep efficiency in emergency medicine residents working night shifts. Academic Emergency Med 2000;7:955-8.

32 Jorgensen KM, Witting MD. Does exogenous melatonin improve day sleep or night alertness in emergency physicians working night shifts? Ann Emergency Med 1998;31:699-704.

33 Petrie K, Conaglen JV, Thompson L, Chamberlain K. Effect of melatonin on jet lag after long haul flights. BMJ 1989;298:705-7. 


\section{Research}

34 Petrie K, Dawson AG, Thompson L, Brook R. A double-blind trial of melatonin as a treatment for jet lag in international cabin crew. Biol Psychiatry 1993;33:526-30.

35 Suhner A, Schlagenhauf P, Johnson R, Tschopp A, Steffen R. Comparative study to determine the optimal melatonin dosage form for the alleviation of jet lag. Chromobiol 1998;15:655-6.

36 Suhner A, Schlagenhauf P, Hofer I, Johnson R, Tschopp A, Steffen R. Effectiveness and tolerability of melatonin and zolpidem for the alleviation of jet lag. Aviation Space Envirommental Med 2001;72:638-46.

37 Waldhauser F, Saletu B, Trinchard-Lugan I. Sleep laboratory investigations on hypnotic properties of melatonin. Psychopharmacol 1990;100:222-6.

38 Wright SW, Lawrence LM, Wrenn KD, Haynes ML, Welch LW, Schlack HM Randomized clinical trial of melatonin after night-shift work: efficacy and Reuropsychologic effects. Ann Fmergency Med 1998;32:334-40.

39 Vallieres A, Morin CM. Actigraphy in the assessment of insomnia. Sleep 2003;26:902-6.

49 Chalmers TC, Celano P, Sacks HS, Smith H Jr. Bias in treatment assignment in controlChalmers TC, Celano P, Sacks HS, Smith HJr. Bias
led clinical trials. N Engl J Med 1983;309:1358-61.

41 Herxheimer A, Petrie KJ. Melatonin for preventing and treating jet lag. Cochrane Database Syst Rev 2002;2:CD001520.

42 Chase JE, Gidal BE. Melatonin: therapeutic use in sleep disorders. Ann Pharmacother 1997;31:1218-26.

(Accepted 18 November 2005) doi 10.1136/bmj.38731.532766.F6

University of Alberta/Capital Health Evidence-based Practice Centre, Department of Pediatrics, University of Alberta, Edmonton, AB, Canada T6G 2J3

Nina Buscemi research associate

Ben Vandermeer statistician

Nicola Hooton project coordinator

Rena Pandya project manager

Lisa Tjosvold research librarian

Lisa Hartling administrative director

Terry P Klassen director

Complementary and Alternative Research and Education Program, Department of Pediatrics, University of Alberta

Sunita Vohra director

Department of Psychiatry, University of Alberta

Glen Baker professor and chair

Correspondence to: N Buscemi nina.buscemi@ualberta.ca 